\title{
ANDROID-BASED LEARNING MEDIA DEVELOPMENT FOR CHEMICAL BALANCE MATERIALS
}

Ramlan Silaban ${ }^{1)}$; Freddy TM Pannggabean ${ }^{2)}$; Melhyada Veronika Panggabean ${ }^{3)}$; Pelita Ananda Sianturi ${ }^{4}$; Irving Josafat Alexander ${ }^{5)}$

\footnotetext{
${ }^{1)}$ Dosen Jurusan Kimia FMIPA Universitas Negeri Medan, Medan; drrsilabanmsi@yahoo.co.id ${ }^{2)}$ Dosen Jurusan Kimia FMIPA Universitas Negeri Medan, Medan; freddypanggabean234@yahoo.com

3) Staf Pengajar Bimbingan EtnoSains Medan; melhyada19@gmail.com

4) Staf Pengajar Bimbingan EtnoSains Medan; plitananda@gmail.com

${ }^{5)}$ Staf Pengajar STIKes Murni Teguh Medan; irvingjosafat7@gmail.com
}

\begin{abstract}
This study aims to obtain an innovative android-based chemistry learning media for Chemical Equilibrium material in Class XII MIA. To achieve this goal, research on the type of development using the 4D method has been carried out. The media obtained were tested for feasibility, referring to the feasibility indicators of learning media in the National Education Standards Agency, BSNP involving expert validators. The research result show that(1) An android-based chemistry learning media (ChemsDroid) has been obtained on chemical equilibrium topic.(2). The ChemsDroid media obtained has met the eligibility criteria based on the National Education Standards Agency (BSNP), namely content feasibility, graphic feasibility, language feasibility and presentation feasibility.(3) The results of the perception test showed that students gave a very good response.
\end{abstract}

Keywords: Android-Based Chemistry Learning Media; Chemical Equilibrium

\section{ABSTRAK}

Penelitian ini bertujuan untuk memperoleh inovasi media pembelajaran kimia berbasis android untuk materi Kesetimbangan Kimia di Kelas XII MIA. Untuk mencapai tujuan tersebut telah dilakukan penelitian tentang jenis pengembangan dengan menggunakan metode 4D. Media yang diperoleh diuji kelayakannya, mengacu pada indikator kelayakan media pembelajaran di Badan Standar Nasional Pendidikan, BSNP dengan melibatkan validator ahli. Hasil penelitian menunjukkan bahwa (1) Telah diperoleh media pembelajaran kimia berbasis android (ChemsDroid) pada materi kesetimbangan kimia.(2). Media ChemsDroid yang diperoleh telah memenuhi kriteria kelayakan berdasarkan Badan Standar Nasional Pendidikan (BSNP), yaitu kelayakan isi, kelayakan grafis, kelayakan bahasa dan kelayakan penyajian. (3) Hasil uji persepsi menunjukkan peserta didik memberikan respon yang sangat baik.

Kata kunci: Media; Pembelajaran Kimia Berbasis Android; Kesetimbangan Kimia

\section{PENDAHULUAN}

Perkembangan ilmu pengetahuan dan teknologi yang begitu pesat sekarang ini, menuntut pendidikan untuk turut serta dalam penggunaan teknologi sebagai bentuk inovasi dalam pembelajaran (Darling- Hammond \& Bransford, 2005).
Dalam melaksanakan kegiatan pembelajaran, guru tentunya seringkali menggunakan strategi pembelajaran yang beragam dan harus memahami kondisi dan situasi dari masing - masing kegiatan pembelajaran. Sementara dengan memanfaatkan bahan ajar dengan media 
pembelajaran yang telah dirancang sesuai dengan kebutuhan pembelajaran, peserta didik diarahkan untuk menjadikan pembelajaran yang aktif karena peserta didik dapat membaca dan mempelajari materi. (Silaban et al .,2015).

Penggunaan media dapat meningkatkan prestasi dan motivasi belajar peserta didik. Gambar ataupun animasimerupakan media pembelajaran membuat proses pembelajaran lebih menarik. Kemenarikan tampilan fisik sangat mempengaruhi proses pembelajaran, semakin menarik tampilan media maka peserta didik semakin termotivasi untuk belajar sehingga mempengaruhi hasil belajar peserta didik (Resiani,2015).

Kemajuan teknologi adalah sesuatu yang tidak bisa dihindari dalam kehidupan ini, karena kemajuan teknologi akan berjalan sesuai dengan kemajuan ilmu pengetahuan (Juwitaningsih \& Rilanty, 2020). Teknologi digunakan sebagai media pembelajaran inovatif yang diyakini mampu mengikuti perkembangan zaman. Pengaruh teknologi terhadap pembelajaran dapat meningkatkan hasil belajar. Contoh Perangkat android digunakan sebagai media pembelajaran yang bermanfaat bagi peserta didik. (Sakat et al .,2012).

Dikembangkannya media pembelajaran yang memanfaatkan perangkat mobile artinya peserta didik akan dapat mengakses dan belajar di manapun dan kapanpun. Hal ini berarti peserta didik akan semakin berperan aktif dalam pembelajaran sesuai dengan amanat kurikulum 2013 yang menekankan peserta didik sebagai pusat pembelajaran (Solihah et al ., 2015)

Berdasarkan pengalaman peneliti juga pada saat melaksanakan kegiatan observasi di SMA Negeri 1 Perbaungan. Peserta didik di sekolah tersebut masih banyak yang kurang tertarik belajar kimia. Hal ini disebabkan kurang menariknya media yang digunakan dan masih ada guru yang menggunakan metode ceramah dan hanya menggunakan power point sebagai media, sehingga peserta didik merasa bosan dan tak jarang lebih memilih untuk bermain dengan android masing-masing. Apalagi di sekolah tersebut memperbolehkan para peserta didik untuk membawa android dan alat komunikasi lainnya ke sekolah.

Berdasarkan beberapa penelitian sebelumnya pengembangan media pembelajaran diperlukan untuk mampu mengatasi masalah-masalah dalam proses belajar dan dapat meningkatkan hasil belajar peserta didik. Salah satu bentuk dari pengembangan media yang nyaman dan menarik bagi peserta didik, seperti media belajar berbasis android.

Adapun tujuan dari penelitian ini adalah untuk mengetahui kelayakan media pembelajaran android yang diterapkan pada pembelajaran berdasarkan standard 
BSNP (Badan Standar Nasional

Pendidikan).

Media pembelajaranlebih efektif dan efesien digunakan sebagai perantara antara guru dan peserta didik dalam memahami materi pembelajaran, sehingga materi pembelajaran lebih cepat diterima peserta didik dengan utuh serta menarik minat peserta didik untuk belajar lebih lanjut (Musfiqon,2011).

Fungsi dari media pembelajaran dapat dituliskan sebagai berikut : (1) Media Pembelajaran Sebagai Sumber Belajar, yaitu media pembelajaran sebagai sumber belajar. Dalam kalimat sumber belajar ini tersirat makna keaktifan yaitu sebagai penyalur, penyampai, penghubung dan lain-lain. Fungsi media pembelajaran sebagai sumber belajar adalah fungsi utamanya disamping adanya fungsi-fungsi lainnya. (2) Fungsi Semantik, adalah kemampuan media dalam menambah pembendaharaan kata yang makna atau maksudnya benar-benar dipahami oleh anak didik. Bahasa meliputi lambang (simbol) dari isi yakni pikiran atau perasaan yang keduanya telah menjadi totalitas pesan yang tidak dapat dipisahkan.

(3) Fungsi manipulatif, ini didasarkan pada ciri-ciri umum yaitu kemampuan merekam, menyimpan, melestarikan, merekonstruksikan dan metransportasi suatu peristiwa atau objek. Berdasarkan karakteristik umum ini, media memiliki dua kemampuan, yakni mengatasi batas- batas ruang dan waktu, mengatasi keterbatasan inderawi, (4) Fungsi psikologis, terdiri dari: a) Atensi, b) Afektif, c) Kognitif, d) Imajinatif, e) Motivasi, f) Sosio-Kultural.

Penggunaan media dalam proses pembelajaran mampu memberikan banyak manfaat. Adanya media pembelajaran dapat mengatasi masalah keterbatasan ruang dan waktu. Media pembelajaran berbasis android juga dapat digunakan untuk merangsang antusias peserta didik dalam mengikuti pembelajaran di kelas.

Android adalah sistem operasi berbasis Linux yang dirancang untuk perangkat bergerak layar sentuh seperti telepon pintar dan computer tablet. Android awalnya dikembangkan oleh Android, Inc dengan dukungan financial Google, yang kemudian membelinya pada tahun 2005 (Kusniaty dan Sitanggang,2016). Media pembelajaran berbasis android biasanya dibuat dalam sebuah menu sederhana yang berisi materimateri pembelajaran beserta soal-soal latihan dan contoh soal. Penelitian yang telah dilakukan Donasari tahun 2021, telah menghasilkan satu media pembelajaran berbasis Android untuk mengajarkan Termokimia di Kelas XI SMA (Donasari, 2021). Tertarik akan hal disebutkan, penelitian ini mengembangkan media pembelajaran kimia berbasis Android untuk mengajarkan Kesetimbangan Kimia. Selain itu untuk menarik perhatian 
pengguna atau peserta didik didalamnya juga dimuat fitur-fitur pendukung seperti gambar, animasi, video, suara yang berkenaan dengan materi atau pelajaran serta tampilan warna yang menarik.

Penelitian pengembangan atau Research and development ( $\mathrm{R} \& \mathrm{D})$ adalah proses yang digunakan untuk mengembangkan dan memvalidasi produk pendidikan.

Karakteristik penelitian pengembangan antara lain: (1) masalah yang ingin dipecahkan adalah masalah nyata yang berkaitan dengan upaya inovatif atau penerapan teknologi dalam pembelajaran sebagai pertanggungjawaban profesional dan komitmennya terhadap pemerolehan kualitas belajar; pengembangan model, pendekatan dan metode pembelajaran, serta media belajar yang menunjang keefektifan pencapaian kompetensi peserta didik, (3) Proses pengembangan produk, validasi yang dilakukan oleh validator kemudian dilakukan uji skala luas. Proses pengembangan, validasi, dan uji coba lapangan tersebut seyogyanya dijelaskan secara jelas, sehingga dapat dipertanggungjawabkan secara akademik (4). Proses pengembangan model, pendekatan, modul, metode, dan media pembelajaran perlu didokumentasikan secara rapi (Wayan,2009).

\section{METODE PENELITIAN}

Jenis penelitian yang digunakan dalam penelitian ini adalah jenis penelitian pengembangan atau Research and Development (R\&D). Desain yang digunakan dalam penelitian ini yaitu desain penelitian pengembangan model 4-D. Menurut Thiagrajan (1974: 5), Model pengembangan 4-D terdiri atas 4 tahap utama yaitu: Define (Pendefinisian), Design (Perencanaan), Develop (Pengembangan) dan Disseminate (Penyebaran). Dalam penelitian ini, yang dilaporkan hanya sampai tahap pengembangan saja.

Penelitian ini akan dilakukan di SMA Negeri 1 Perbaungan dengan lokasi Jalan Mayjend H.T. Rizal Nurdin, Perbaungan. Penelitian ini dilaksanakan pada bulan Januari 2021 semester genap pada tahun ajaran 2020/2021.

Sampel dalam penelitian ini terdiri dari satu kelas peserta didik kelas XII MIA. Sampel diperoleh menggunakan teknik Total Sampling. Sebagai validator media yang telah dikembangkan dibutuhkan 3 orang dosen kimia Universitas Negeri Medan, dan 2 orang guru kimia SMA Negeri 1 Perbaungan.

Instrumen yang digunakan dalam penelitian ini adalah instrumen nontes.instrument non tes berupa angket validasi kelayakan media berdasarkan BSNP dan angket respon peserta didik 
terhadap media pembelajaran berbasis android.

Pada analisis data untuk analisis kategori kelayakan validasi media berdasarkan BSNP apabila dalam angket diperoleh data seperti Tabel 1 berikut:

Tabel 1.Kategori Kelayakan Media

\begin{tabular}{|c|c|c|}
\hline No & $\begin{array}{c}\text { Skor Rata- } \\
\text { Rata }\end{array}$ & Kategori Kelayakan \\
\hline 1 & $3.5 \leq \mathrm{P} \leq 4$ & Sangat Valid \\
\hline 2 & $3 \leq \mathrm{P}<3.5$ & Valid \\
\hline 3 & $2.5 \leq \mathrm{P}<3$ & Kurang Valid \\
\hline 4 & $\mathrm{P}<2.5$ & Sangat Kurang Valid \\
\hline \multicolumn{3}{|c|}{ Analisis respon peserta didik, hasil }
\end{tabular}

persentase agket respon peserta dapat dilihat dengan kategori seperi di dalam tabel berikut:

Tabel 2. Kategori Kelayakan Hasil Respon Peserta didik Terhadap Media

\begin{tabular}{|c|c|c|}
\hline No & Angka & Kategori \\
\hline 1 & $0-10 \%$ & Sangat Kurang \\
\hline 2 & $11-40 \%$ & Kurang \\
\hline 3 & $41-60 \%$ & Cukup \\
\hline 4 & $61-90 \%$ & Baik \\
\hline 5 & $91-100 \%$ & Sangat Baik \\
\hline
\end{tabular}

\section{HASIL DAN PEMBAHASAN}

\section{Analisis Kurikulum}

Analisis kurikulum dilakukan dengan memperhatikan karakteristik kurikulum yang sedang digunakan dalam suatu sekolah. Pengembangan media dibuat sesuai dengan tuntutan kurikulum yang berlaku. Kurikulum yang digunakan di SMA Negeri 1 Perbaungan adalah Kurikulum 2013 (K-13), kemudian, peneliti mengkaji KD untuk merumuskan indikator-indikator

pencapaian

pembelajaran.

\section{Analisis Karakteristik Peserta Didik}

Karakteristik dari pada peserta didik kelas XII kimia SMA Negeri 1 Perbaungan dalam menangkap materi kimia berbeda-beda terlebih terkait materi kimia yang bersifat abstrak dan mikroskopis. Penyesuaian terhadap cara penyampaian materi mempermudah peserta didik memahaminya. Berdasarkan temuan tersebut, produk media pembelajaran dikembangkan dan disusun dengan penyampaian materi, kesetimbangan kimia yang disesuaikan dengan perkembangan kognitif peserta didik SMA. Adapun produk aplikasi tersebut memuat penjelasan dan visualisasi yang terdapat pada materi kesetimbangan kimia, sehingga dihasilkan produk berupa Media Kimia Android (Chems Droid). Media pembelajaran mandiri kimia pada materi Kesetimbangan Kimia yang disesuaikan dengan karakteristik peserta didik SMA.

Pengembangan bahan ajar berbasis android adalah untuk menganalisis bahan ajar yang digunakan oleh peserta didik SMA Negeri 1 Perbaungan yaitu buku Kimia SMA tahun 2016.

\section{Tahap Perencanaan}

Media Chems Droid (Kimia Android) yang dikembangkan mempresentasikan media pembelajaran 
berbasis aplikasi android yang dirancang agar penyampaian materi kimia dapat dipahami oleh peserta didik. Media Kimia Android ini berisi tentang penjelasan mengenai materi pokok kesetimbangan kimia.

Gambaran desain awal media yang akan dikembangkan berbasis android yang dapat dilihat pada Gambar1:

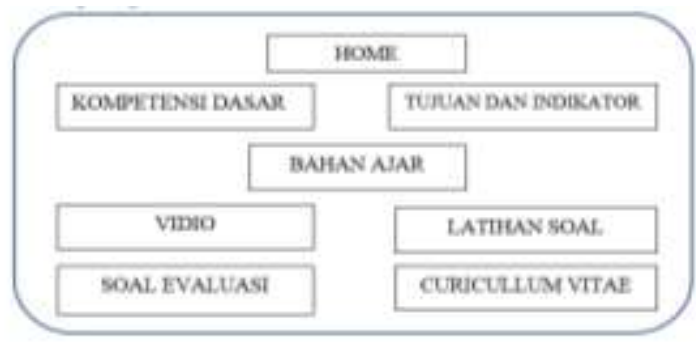

Gambar 1. Gambaran Menu Media Pembelajaran Berbasis Android (Chems Droid)

\section{Tahap Pengembangan}

Produk awal media pembelajaran interaktif berbasis android meliputi logo aplikasi, halaman awal atau beranda kemudian halaman isi.

Bentuk logo media pembelajaran yang telah di install pada android dapat dilihat pada gambar 2:

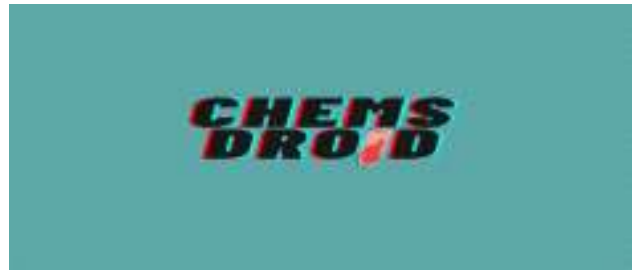

Gambar 2. Gambaran Logo Media Chems Droid

Media pembelajaran kimia berbasis android ini memiliki tampilan awal yaitu berupa judul media dan menu utama yaitu halaman untuk log in dapat dilihat pada Gambar 3:

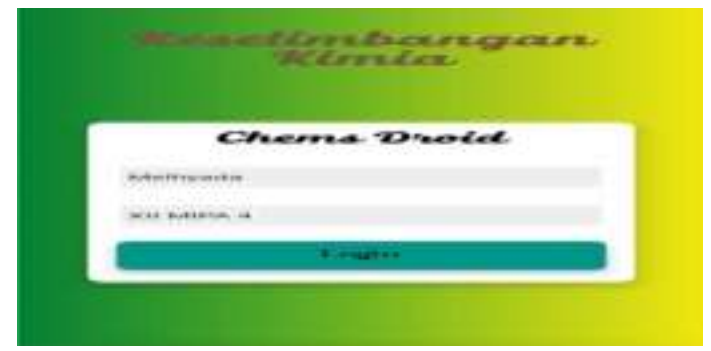

Gambar 3. Tampilan Awal Menu Media kimia Android

Tampilan menu utama setelah login terdiri dari 7 menu utama yang terdiri dari Kompetensi, Tujuan dan Indikator, Bahan Ajar, Video Pembelajaran, Latihan Saol, Soal Evaluasi, dan Curicullum Vitae (CV) dapat dilihat pada Gambar 4:

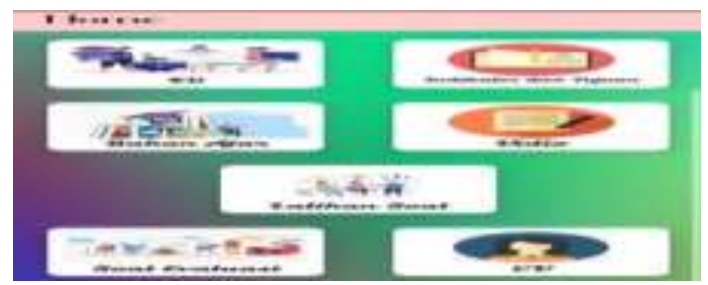

Gambar 4. Tampilan Menu Utama Aplikasi Media Pembelajaran Kimia berbasis Android

Menu Pendahuluan terdiri dari Kompetensi Inti (KI), Kompetensi Dasar (KD), Indikator dan Tujuan Pembelajaran dapat dilihat pada gambar 5:

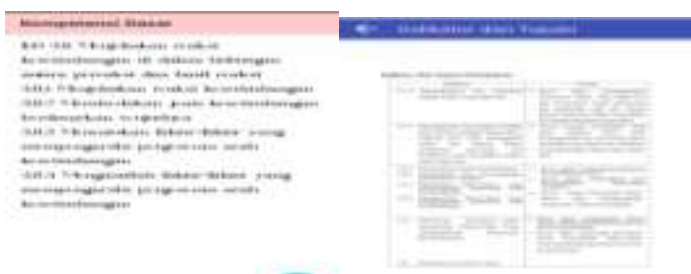

Gambar 5. Tampilan Menu Kompetensi Dasar dan Indikator Tujuan Pembelajaran Pada Aplikasi Media Pembelajaran kimia berbasis Android

Menu materi merupakan kumpulan dari materi-materi pembelajaran 
kesetimbangan kimia.Tampilan menu ini dapat dilihat pada Gambar 6:

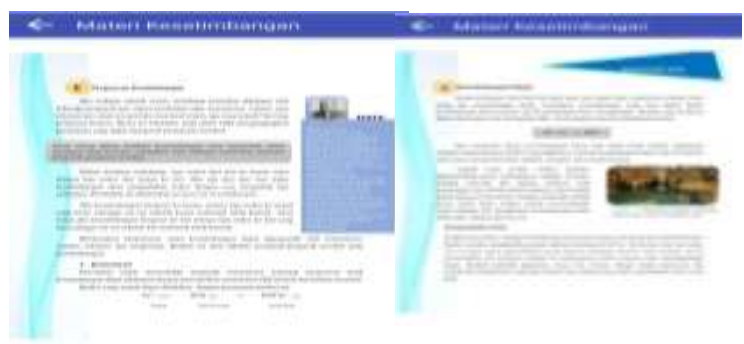

Gambar 6. Tampilan menu Materi pada Aplikasi Media Pembelajaran Kimia berbasis Android

Selanjutnya menu video yang berisi video pembelajaran dan video praktikum.Terdapat dua video dimana video pertama merupakan video pembelajaran yang menjelaskan materi kesetimbangan kimia. Secara singkat dan pada video kedua berisi praktikum sederhana yang mudah dipraktikkan oleh peserta didik secara mandiri sesuai dengan materi kesetimbangan kimia. Selain pembelajaran secara visual, media ini juga memberikan pembelajaran secara audio visual dan membantu peserta didik untuk memahami pelajaran laju reaksi. Tampilan ini dapat dilihat pada Gambar 7:

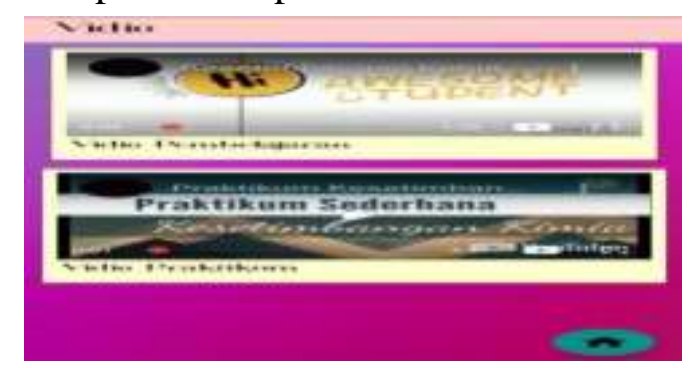

Gambar 7. Tampilan Video Pembelajaran Dan Video Praktikum Pada Media Pembelajaran (ChemsDroid)

Selanjutnya menu latihan merupakan menu yang berisi kumpulan soal-soal pilihan ganda seputar materi kesetimbangan kimia. Peserta didik menjawab soal yang tersedia lalu akan muncul responterhadap jawaban yang dipilih. Jika jawaban benar, makan akan muncul kata "Benar" disertai pembahasan, begitu juga sebaliknya apabila jawaban salah maka akan muncul kata "Salah" disertai pembahasan. Tampilan menu soal latihan dapat dilihat pada Gambar 8:

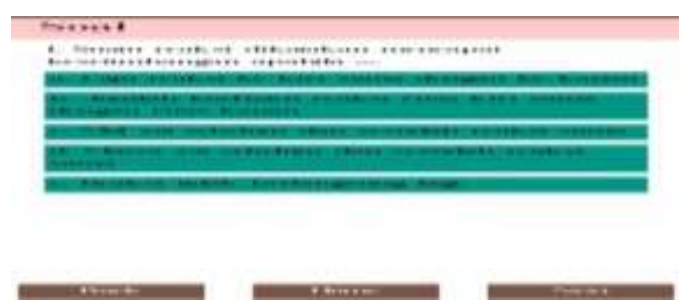

Gambar 8. Tampilan Soal Latihan pada Menu Latihan pada Media Pembelajaran (ChemsDroid)

Setelah menjawab soal, akan tampilan respon benar atau salah disertai pembahasan yang diperoleh peserta didik dengan tampilan seperti pada Gambar 9:

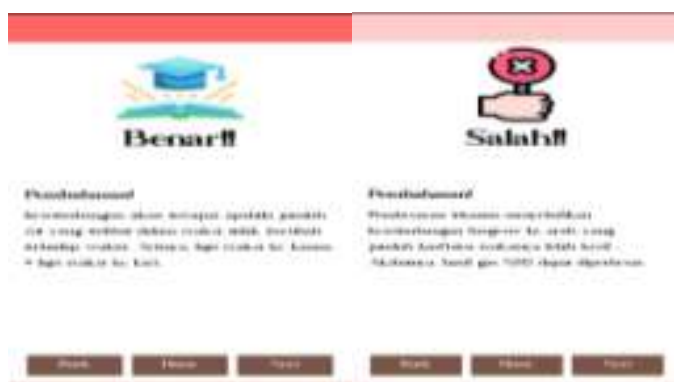

Gambar 9 Tampilan Setelah Menyelesaikan Latihan pada Media Pembelajaran (ChemsDroid)

Menu evaluasi berisi soal-soal berupa soal pilihan ganda yang merupakan soal yang menentukan hasil akhir dari mempelajari materi kesetimbangan kimia melalui media android ini dan setelah selesai memilih jawaban yang tepat, 
diakhir akan ditampilkan skor yang diperoleh peserta didik dengan tampilan Gambar 10:

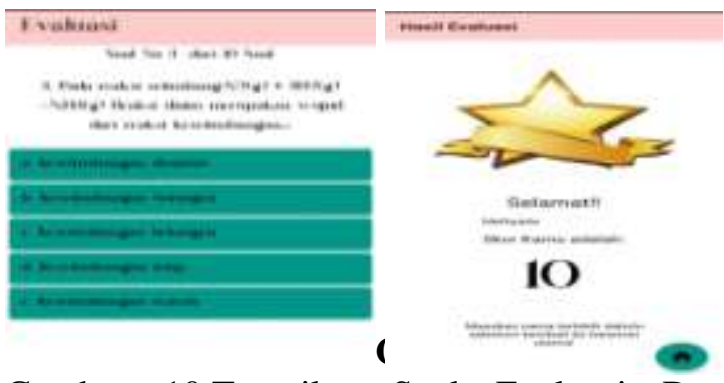

Gambar 10.Tampilan Soal Evaluasi Dan Perolehan Skor Diakhir Menu Evaluasi Media Pembelajaran kimia berbasis Android

Menu yang terakhir adalah menu Curicullum Vitae (CV) berisi riwayat pembuat media ChemsDroid dengan tampilan seperti Gambar 11.

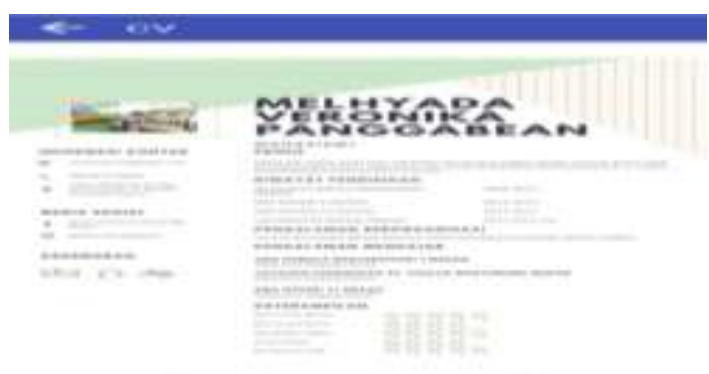

Gambar 11.Tampilan Menu CV Pada Media Pembelajaran kimia berbasis Android

\section{Validasi Media Yang Dikembangkan}

Hasil validasi media berbasis Android (Tabel 3) dan hasil validasi media (Gambar 12) sebagai berikut:

Tabel 3. Hasil Validasi Media yang Dikembangkan Berbasis Android

\begin{tabular}{|c|c|c|c|c|c|c|c|}
\hline \multirow{2}{*}{ Kelnghan BACP } & \multicolumn{5}{|c|}{ 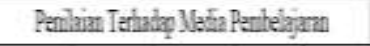 } & \multirow{2}{*}{ Rathrath } & \multirow{2}{*}{ Keteragn } \\
\hline & Desen 1 & Dosan? & Dosen 1 & Gin 1 & Gm? & & \\
\hline Kelyentanti & 554 & 3.55 & 3.53 & 3,55 & 3.4 & 354 & SV \\
\hline Kelogylun Bahass & 364 & 3.64 & 3,57 & 3,57 & 3,59 & 368 & SV \\
\hline 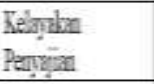 & 561 & 3.57 & 3,71 & 3,8 & 3,71 & 366 & SV \\
\hline 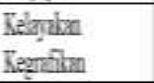 & 366 & 3,61 & 3.61 & 3,69 & 1,69 & 3,63 & 5 \\
\hline
\end{tabular}

\section{Hasil Validasi Media}

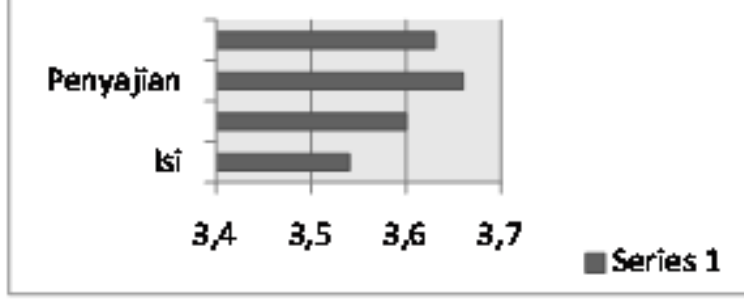

\section{Gambar 12. Hasil Validasi Media}

Berdasarkan Tabel 3 dan Gambar 12 hasil validasi media pembelajaran kimia berbasis android berdasarkan standar BSNP menunjukkan bahwa diperoleh ratarata kelayakan isi sebesar 3,54 sehingga berdasarkan kelayakan isi media yang dikembangkan sangat valid. Rata-rata kelayakan bahasa dari media yang dikembangkan diperoleh sebesar 3,60 sehingga sehingga berdasarkan kelayakan bahasa media yang dikembangkan sangat valid. Rata-rata kelayakan penyajian media yang dikembangkan diperoleh sebesar 3,66 sehingga berdasarkan kelayakan penyajian media yang dikembangkan sangat valid. Rata- rata kelayakan kegrafikan media yang dikembangkan diperoleh sebesar 3,63 sehingga berdasarkan kelayakan kegrafikan media yang dikembangkan sangat valid. Total rata-rata hasil validasi media pembelajaran kimia yang dikembangkan berbasis android pada materi kesetimbangan kimia sebesar 3,61dan dinyatakan sudah sangat valid sehingga tidak perlu direvisi lagi dan sudah dapat diimplementasikan dalam proses pembelajaran materi kesetimbangan kimia. 
Hasil respon peserta didik terhadap media yang dikembangkan ditunjukkan pada tabel 4 sebagai berikut:

Tabel 4. Hasil Respon Peserta didik Terhadap Media Yang Dikembangkan

\begin{tabular}{ll}
\hline Respon Dari Aspek & Rata- Rata \\
\hline Materi & 3,93 \\
Bahasa & 3,91 \\
Soal & 3,95 \\
Video & 3,91 \\
Keterlaksanaan & 3,95 \\
Perangkat Lunak & 3,92 \\
Komunikasi Verbal & 3,90 \\
Minat Terhadap Media & 3,91 \\
\hline
\end{tabular}

Berdasarkan Tabel 4 menunjukkan bahwa rata-rata hasil respon peserta didik terhadap media ChemsDroid yang dilihat dari aspek materi diperoleh rata-rata sebesar 3,93. Rata-rata aspek bahasa dari media diperoleh sebesar 3,9. Rata-rata aspek soal pada media diperoleh sebesar 3,95. Rata-rata dari aspek video pada media diperoleh sebesar 3,91. Rata-rata dari aspek keterlaksanaan diperoleh sebesar 3,95. Rata-rata aspek perangkat lunak pada media diperoleh sebesar 3,92. Rata-rata dari aspek komunikasi verbal pada media diperoleh sebesar 3,90. Ratarata dari aspek minat terhadap media diperoleh sebesar 3,91. Dan total persentase sebesar 3,92 dimana media android ChemsDroid pada materi kesetimbangan kimia ternyata di respon sangat baik oleh peserta didik.
Berdasarkan penelitian yang telah dilakukan di SMA Negeri 1 Perbaungan dapat disimpulkan bahwa bahan media pembelajaran berbasis android efektif untuk digunakan dalam kegiatan pembelajaran. Salah satu komponen penting yang berperan dalam peningkatan hasil belajar peserta didik yaitu sumber belajar peserta didik dengan dipermudahnya penyampaian materi. Media android yang dikembangkan dapat digunakan oleh peserta didik kapanpun dan dimanapun tanpa adanya batasan ruang dan waktu, lebih praktis digunakan, dapat digunakan kembali, mudah dibawa, dan interaktif. Hal ini sesuai dengan Arsyad (2013) yang menyatakan bahwa bahan ajar yang baik untuk meningkatkan hasil belajar adalah bahan ajar yang memiliki interaktifitas, yaitu bahan ajar yang dapat memunculkan komunikasi dua arah. Hal ini juga sesuai dengan penelitian yang dilakukan oleh Sakat, dkk (2012) bahwa menggunakan media berbasis teknologi dapat meningkatkan motivasi belajar dan membuat pembelajaran menjadi lebih atraktif, menarik dan menyenangkan

\section{SIMPULAN DAN SARAN \\ SIMPULAN}

Media ChemsDroid telah memenuhi kriteria kelayakan berdasarkan Badan Standard Nasional Pendidikan (BSNP), yaitu kelayakan isi,kelayakan kegrafikaan, kelayakan bahasa dan kelayakan penyajian. 
Respon peserta didik sangat baik terhadap media pembelajaran kimia berbasis android (ChemsDroid).

\section{SARAN}

Media pembelajaran kimia berbasis Android dapat digunakan untuk materi kesetimbangan kimia.

\section{UCAPAN TERIMAKASIH}

Kepada Kepala Sekolah SMA Negeri

1 Perbaungan, kami ucapkan terimakasih atas kerjasamanya dalam perizinan dan memfasilitasi penelitian ini dapat terlaksana dengan baik.

\section{DAFTAR PUSTAKA}

Azhar Arsyad. 2013. Media Pembelajaran. Jakarta: Rajagrafindo Persada;

Darling-Hammond, L., \& Bransford, J. (2005). Preparing teachers for a changing world: What teachers should learn and be able to do. San Francisco: Jossey-Bass;

Donasari, A., Silaban, R. (2021), Pengembangan media pembelajaran kimia berbasis androi pada materi Termokimia Kelas XI SMA, Jurnal Inovasi Pembelajaran Kimia, Vol. 3 No 1 , 2021. https://jurnal.unimed.ac.id/2012/inde x.php/jipk/article/view/23056

DOI: https://doi.org/10.24114/jipk.v3 i1.2305;

Juwitaningsih, T dan Rilanty, N. (2020). Pengembangan Media Pembelajaran Berbasis Website Untuk Meningkatkan Hasil Belajar Peserta didik Pada Materi Kesetimbangan Kimia. Jurnal Inovasi Pembelajaran Kimia. 2(1). 36-40;
Kusniyati, H., dan Sitanggang, N.S.P.(2016). Aplikasi Edukasi Budaya Toba Samosir Berbasis Android . Jurnal Teknik Informatika .9(1) : 9-18;

Musfiqon . (2011) . Panduan Lengkap Metodologi Penelitian Pendidikan.Jakarta: PT. Prestasi Pustakaraya;

Resiani, Ni Kadek, Anak Agung Gede Agung, I Nyoman Jampel. (2015). Pengembangan Game edukasi Interaktif Pada Mata Pelajaran IPS Peserta didik Kelas VII Semester Genap di SMP N 7 Singaraja Tahun Ajaran 2014/2015. e-Journal Edutech Universitas Pendidikan Ganesha Jurusan Teknologi Pendidikan, 3(1);

Sakat, A. A., Mohd. Zin, M. Z., Muhammad, R., Ahmad, A., Ahmad, N. A., dan Kamo, M. A. (2012). Educational Technology Media Method In Teaching And Learning Progress. American Journal of Applied Sciences. 9(6) : 874-878;

Silaban,R.,Bronika,S.,Wesly,H.,(2015), Penyusunan Bahan Ajar Kimia Inovatif Materi Laju Reaksi Terintegrasi Pendidikan Karakter Peserta didik SMA , Jurnal Tabularasa PPS Unimed, 12(1):7888;

Solihah, M ., Yektyastuti, R ., \& Prasetyo, $\quad$ Y.D. (2015). Pengembangan Media Pembelajaran Kimia Berbasis Android Sebagai Suplemen Materi Asam Basa Berdasarkan Kurikulum 2013. Seminar Nasional Pendidikan Sains : 457-467;

Thiagarajan, Sivasailam; And Others.1974. "Instructional Development for Training Teachers of Exceptional Children: A Sourcebook." Indiana Univ., Bloomington. Center for Innovation In. (Mc). 
Wayan, S . (2009) . Metode Penelitian Pengembangan dan Teori Pengembangan Modul, Makalah penelitian bagi guru TK, SD, SMP,
SMA dan SMK tanggal 12-14 Januari 2009 di Kecamatan Nusa Penida Kabupaten Klukun. 